\title{
PENGARUH CURRENT ACCOUNT SA VING ACCOUNT (CASA), LOAN TO DEPOSIT RATIO (LDR), DAN NET PERFORMING LOAN (NPL) TERHADAP LABA BERSIH PERUSAHAAN PERBANKAN YANG TERDAFTAR DI BEI PERIODE 2016-2020
}

\author{
${ }^{a}$ Komang Sri Widiantari, bKadek Aditya Yogi Iswara \\ ab Universitas Pendidikan Nasional \\ widiantari@undiknas.ac.id
}

Received : September
Accepted: October
Published: December

\section{ABSTRAK}

Penelitian ini memiliki tujuan melihat adanya pengaruh CASA, LDR dan NPL terhadap laba bersih perusahaan perbankan yang terdaftar di BEI periode 2016 - 2020. Metode kuantitatif digunakan dalam penelitian ini dengan teknik pengumpulan data berupa studi dokumentasi pada data sekunder berupa laporan keuangan periode 2016-2020 dan penelitian terdahulu sedangkan untuk teknik analisis menggunakan Regresi Linier Berganda melalui program IBM SPSS versi 24. Penelitian ini mendapat hasil (1) CASA berpengaruh positif terhadap laba bersih perusahaan perbankan yang terdaftar di BEI periode 2016-2020 (2) LDR tidak berpengaruh terhadap laba bersih perusahaan perbankan yang terdaftar di BEl periode 2016-2020 dan (3) NPL berpengaruh negatif terhadap laba bersih perusahaan perbankan yang terdaftar di BEI periode 2016-2020. Penelitian ini diharapkan dapat membuka wawasan kepada investor terkait analisis fundamental perusahaan perbankan yang dapat dijadikan pertimbangan dalam berinvestasi.

Kata Kunci : Current Account Saving Account, Loan To Deposit Ratio, Non Performing Loan, Laba Bersih

\section{ABSTRACT}

This study has the aim of looking at the effect of CASA, LDR and NPL on the net income of banking companies listed on the IDX for the period 2016 - 2020. Quantitative methods are used in this study with data collection techniques in the form of documentation studies on secondary data in the form of financial statements for the 2016-2020 period and previous research while for the analysis technique using Multiple Linear Regression through the IBM SPSS version 24 program. This study got the results (1) CASA has a positive effect on the net income of banking companies listed on the IDX for the period 2016-2020 (2) LDR has no effect on the company's net income banking companies listed on the IDX for the 2016-2020 period and (3) the NPL has a negative effect on the net income of banking companies listed on the IDX for the 2016-2020 period. This research is expected to open insight to investors regarding the fundamental analysis of banking companies that can be taken into consideration in investing.

Keywords : Current Account Saving Account, Loan To Deposit Ratio, Non Performing Loan, Net Income

\section{PENDAHULUAN}

Perkembangan teknologi dan digital secara global yang sangat pesat saat ini telah membuat disrupsi yang cukup besar di berbagai sektor industri global. Ditambah lagi terjadinya 
pandemi Covid 19 yang melanda dunia menyebabkan perubahan yang signifikan dalam perkembangan teknologi dan digital saat ini. Perubahan tersebut tentu harus diimbangi dengan kesiapan dunia untuk beradaptasi sehingga dapat memunculkan peluang baru dengan memanfaatkan perkembangan teknologi yang pesat saat ini. Termasuk pada sektor ekonomi, secara global peran pertumbuhan sektor ekonomi cukup banyak dipengaruhi oleh perananan pasar modal. Pasar modal memiliki peran yang penting bagi pertumbuhan ekonomi setiap negara, karena memiliki dua fungsi, pertama sebagai wadah bagi perusahaan untuk memperoleh pendanaan dan kedua sebagai wadah bagi masyarakat untuk berinvestasi. Sebagai salah satu instrumen investasi, saham merupakan pilihan yang menarik bagi investor karena dapat memberikan tingkat keuntungan yang diharapkan. Saham merupakan bukti kepemilikan perusahaan yang dibuktikan berdasarkan kepemilikan lembar saham (Fahmi, 2012). Dengan memiliki saham, investor tersebut memiliki perusahaan yang diinvestasikan, namun tergantung pada porsi kepemilikan di saham tersebut.

Indonesia merupakan negara yang menarik untuk berinvestasi. Untuk berinvestasi di Indonesia ada regulator yang mengatur jalannya aktivitas perdagangan di pasar modal Indonesia, yakni Bursa Efek Indonesia. Hingga kini perkembangan investor di Indonesia begitu pesat. Hal tersebut tercermin dari data publikasi yang diterbitkan PT Kustodian Sentral Efek Indonesia (KSEI) per juli 2021. Hingga bulan Juli 2021 jumlah investor saham mencapai lebih dari 2,5 juta, atau meningkat 52\% dibandingkan bulan desember 2020 sebesar 1,69 juta investor. Sedangkan, total investor pasar modal Indonesia sebanyak 5,8 juta investor pada akhir Juli 2021, atau meningkat sekitar 50\% dari Desember 2020 sebanyak 3,88 juta. Namun perkembangan investor di Indonesia masih sedikit tertinggal dibanding lain. Menurut Donny Hutabarat, " dengan total penduduk Indonesia usia produktif sekitar 189 juta dan total investor ritel di pasar modal 4,16 juta, jika dibagi rasionya hanya 2,2 persen, Rasio tersebut sangat kecil yakni dibawah 5\% jika dibandingkan dengan negara lain seperti singapura $26 \%$ dan malaysia 9\%" (kompas.com, 2020). Berdasarkan beberapa data diatas, tentu membuat potensi pasar investasi di Indonesia sangat besar yang berdampak pada semakin sadarnya masyarakat untuk berinvestasi sehingga dapat memperbesar potensi keuntungan tersebut namun harus diiringi pengetahuan atau literasi mengenai investasi saham.

Salah satu sektor yang menarik untuk diinvestasikan di indonesia yakni di sektor perbankan. Sektor perbankan merupakan sektor penggerak bagi perekonomian di Indonesia, karena memiliki fungsi dasar sebagai penerima dana masyarakat kemudian disalurkan sebagai kredit baik kepada perusahaan maupun individu. Saat ini kondisi perbankan sampai triwulan 1 2021 masih solid, hal ini tercermin dari kondisi permodalan bank yang baik dengan rasio permodalan $24.05 \%$. Hal tersebut menandakan kemampuan bank yang cukup kuat dalam mengatasi risiko (OJK, 2021). Dengan cukup tangguhnya sektor perbankan di Indonesia saat ini maka peluang untuk berinvestasi di sektor perbankan menjadi semakin menarik.

Ketika ingin berinvestasi pada sektor perbankan, tentu harus memiliki pengetahuan mengenai fundamental dari perbankan tersebut, bagaimana tingkat kesehatan bank tersebut serta layak tidaknya digunakan untuk investasi selama beberapa periode mendatang. Salah satu cara untuk menilai tingkat kesehatan bank serta fundamentalnya yakni melalui laporan keuangan. Didalam laporan keuangan disajikan lengkap baik rasio keuangan maupun kinerja dari bank tersebut yang disajikan dalam periode tertentu. Untuk mengetahui tingkat kesehatan bank serta kelayakan untuk diinvestasikan terdapat beberapa rasio dari laporan keuangan yang dapat digunakan diantaranya rasio CASA, LDR dan NPL. Kemudian untuk mengetahui bank tersebut memiliki kinerja yang bagus juga dapat dilihat dari bagaiamana perbankan tersebut menghasilkan laba nya. Jika bank mengalami pertumbuhan laba yang konsisten selama periode tertentu maka bank tersebut memiliki kinerja yang baik dan stabil serta dapat dijadikan referensi ketika ingin berinvestasi.

Rasio ini penting untuk dipahami investor karena dapat digunakan untuk menganalisa saham di sektor perbankan. Dengan mengetahui ketiga rasio tersebut serta hubungannya dengan laba bersih yang dihasilkan, maka investor semakin mengetahui kinerja dari bank mana yang ing in 
diinvestasikan atau memiliki referensi mengenai kinerja saham perbankan di Bursa Efek Indonesia. Kecenderungan investor saat ini terutama investor ritel atau individual adalah mereka hanya memilih saham berdasarkan rekomendasi atau referensi teman tanpa melalukan analisa secara mandiri mengenai saham yang ingin diinvestasikan. Mereka hanya memiih sektor yang memiliki potensi bagus di Indonesia tetapi kurang memahami bagaimana kinerja dari saham atau perusahaan yang ingin diinvestasikan tersebut. Maka dari itu penelitian yang berjudul "Pengaruh CASA, LDR dan NPL terhadap laba bersih perusahaan perbankan yang terdaftar di BEI periode 2016-2020' ini penting untuk dilakukan yang menekankan seberapa besar laba bersih perbankan yang dipengaruhi oleh rasio-rasio dalam penelitian ini dan diharapkan memberi kontribusi bagi investor dalam menganalisis lebih jauh mengenai kinerja perusahaan yang ingin diinvestasikan atau sebagai referensi untuk menambah insight dari data-data yang ada di penelitian ini. Dalam penelitian ini terdapat beberapa pembaharuan dari penelitian sebelumnya diantaranya, adanya variabel CASA dan tahun peneliian terbaru sehingga menjadikan penelitian ini tetap relevan.

\section{TINJAUAN PUSTAKA}

\section{Landasan Teori \\ Signaling theory}

Grand theory pada penelitian ini adalah Signalling theory yang merupakan sikap yang dilakukan manajemen untuk memberikan sinyal atau pandangan kepada investor mengenai bagaimana kinerja perusahaannya (Brigham, Eugene F. dan Houston, 2011). Sinyal ini berupa informasi tentang rencana manajemen kedepannya mengenai perusahaannya. Informasi tersebut sangat penting bagi pihak eksternal termasuk investor, karena dapat berpengaruh terhadap keputusan investasi.

\section{Rasio Keuangan}

Kinerja perusahaan dapat dikukur melalui rasio keuangan. Umumnya rasio keuangan yang digunakan berasal dari periode tertentu kemudian dibandingan dengan periode sebelumnya untuk memberikan gambaran perkembangan kinerja. Menurut Kasmir (2014), rasio keuangan yaitu perbandingan angka-angka yang terdapat pada pos laporan keuangan. Umumnya rasio yang digunakan pada perusahaan perbankan dibagi menjadi:

1. Rasio Rentabilitas, Menurut kasmir (2014), Rentabilitas adalah rasio untuk mengukur efektivitas operasional perbankan. Rasio yang dapat digunakan yaitu Current Account Saving Account.

2. Rasio Likuiditas, biasanya digunakan menilai kapasitas perbankan untuk memenuhi kewajiban jangka pendek. Rasio yang dapat digunakan yaitu Loan To Deposit Ratio.

3. Rasio Solvabilitas Menurut kasmir (2010) adalah rasio untuk mengukur kapasitas bank dalam memenuhi kewajiban jangka pendek dan jangka panjang.

4. Rasio kualitas aset. Digunakan untuk mengukur kualitas aset yang dimiliki oleh perbankan dalam menyalurkan kreditnya. Rasio yang dapat digunakan yaitu Non Performing Loan.

\section{Definisi Operasional Variabel \\ Current Account Saving Account}

Menurut Karim (2013), CASA merupakan dana pihak ketiga berupa tabungan dan giro yang memberikan bunga yang lebih terjangkau dari deposito. Tabungan dan giro merupakan "dana murah" karena bunga yang dibebankan kedua produk perbankan ini lebih rendah dibanding deposito. Selain itu, rasio CASA juga menggambarkan tingkat kesehatan keuangan suatu bank. Perbankan nasional terus berupaya dalam menjaga rasio CASA di kisaran $50 \%$ sampai $60 \%$ dari Total Dana Pihak Ketiga (DPK) agar likuiditas perbankan selalu terjaga dan kuat. (Elfriedwan, 2020). Rasio ini memiliki rumus:

$\mathrm{CASA}=$ Jumlah tabungan dan giro / dana pihak ketiga $\times 100 \%$ 


\section{Loan to Deposit Ratio}

Menurut Dendawijaya (2013) LDR adalah rasio yang menunjukkan tingkat likuiditas perbankan dan kemampuan nya untuk memberikan kredit dari dana pihak ketiga yang dimiliki. LDR umumnya diukur untuk mengetahui likuditas perbankan. Setiap bank biasanya memiliki likuiditas yang berbeda tergantung modal serta ukuran bank. Menurut kasmir (2014) rasio LDR ini idealnya bagi perbankan yakni $80 \%$. Rasio ini memiliki rumus:

$\mathrm{LDR}=$ total kredit / dana pihak ketiga $\times 100 \%$

\section{Non Performing Loan}

NPL merupakan kondisi kesulitan membayar tunggakan kredit atau disebut juga kredit bermasalah (Taswan, 2006). Kredit bermasalah merupakan penilaian kredit kurang lancar, diragukan dan macet. Rasio ini terbilang sehat apabila NPL $<5 \%$ menurut Bank Indonesia. Menurut Hanafi (2014) Bank memiliki risiko kredit (macet atau tidak terbayar), semakin kecil NPL yang dimiliki perbankan semakin kecil juga risikonya. Demikian sebaliknya, semakin besar NPL semakin besar juga risiko dari kredit yang diberikan.

NPL $=$ Kredit bermasalah / Total kredit x 100\%

\section{Laba Bersih}

Laba Bersih adalah pendapatan yang didapatkan setelah dikurangin segala beban operasional maupun non operasional dari suatu perusahaan (Kasmir 2011:303). Laba bersih yang tinggi mencerminkan perbankan atau perusahaan memiliki tingkat efisiensi yang tinggi dalam mengelola bisnisnya. Hal ini tentu meningkatkan kepercayaan publik terutama investor terhadap bank tersebut. Rumus dari laba bersih adalah:

Laba Bersih = Earning Before Interest and Tax (EBIT) - (Pajak+ bunga)

\section{Kerangka Pemikiran}

Berdasarkan latar belakang dan pembahasan teori diatas, didapatkan kerangka pemikiran dari "Pengaruh CASA LDR dan NPL terhadap laba bersih perusahaan perbankan yang terdaftar di BEI periode 2016-2020" ini adalah:

Gambar 1.

Pengaruh CASA LDR NPL terhadap laba bersih perusahaan perbankan yang terdaftar di BEI periode 2016-2020

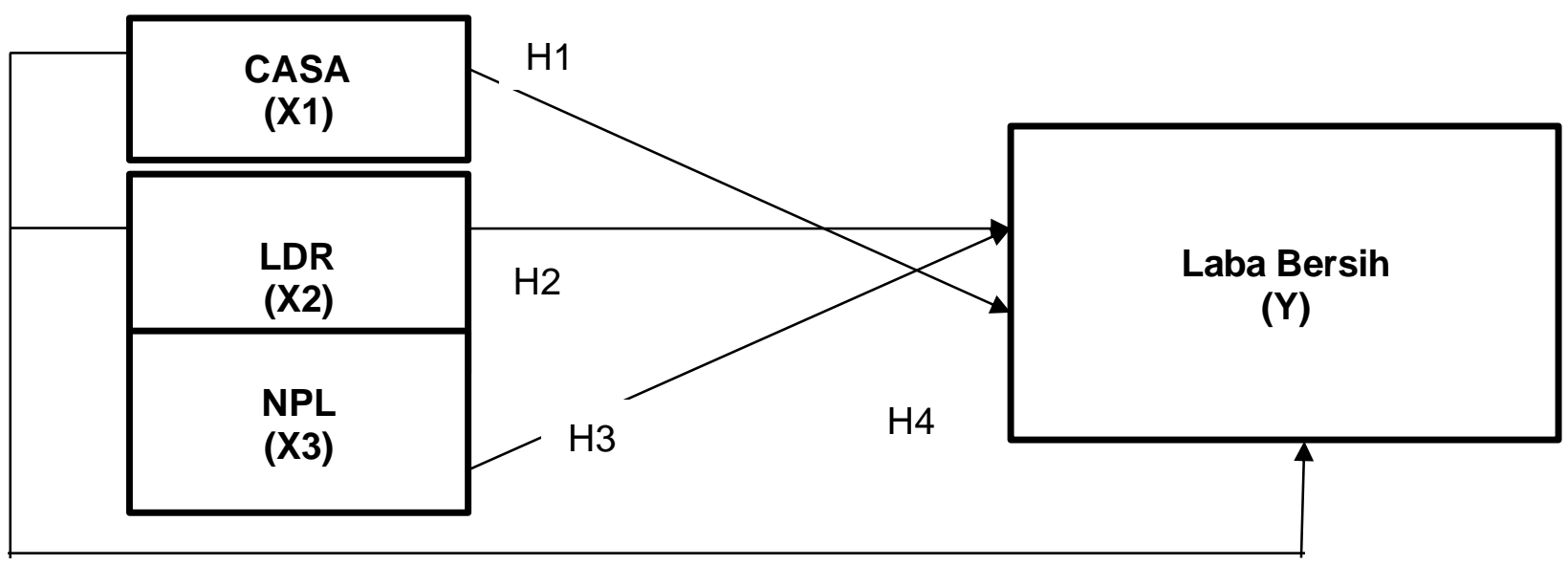




\section{Hipotesis}

Current Account Saving Account (CASA) merupakan rasio untuk menilai tingkat "dana murah" terhadap total dana pihak ketiga yang dihimpun perusahaan. Secara teori jika Current Account Saving Account (CASA) suatu perbankan yang semakin tinggi maka akan cenderung mengurangi beban bunga yang dikeluarkan perbankan untuk menghimpun dana pihak ketiga tersebut. Dengan beban bunga yang lebih rendah tersebut membuka peluang bagi perbankan untuk meningkatkan labanya. Menurut hasil penelitian yang dilakukan oleh Hendrawati (2020), Current Account Saving Account (CASA) berpengaruh positif terhadap Return On Asset (ROA) pada bank umum syariah devisa periode 2015-2019. Kemudian penelitian yang dilakukan oleh Khabibah, dkk (2020) menunjukan Current Account Saving Account CASA berpengaruh terhadap profitabilitas perbankan di Indonesia.

H1: CASA berpengaruh positif terhadap Laba bersih perusahaan perbankan yang terdaftar di BEl

Loan To Deposit Ratio merupakan rasio untuk mengukur likuiditas dengan membandingkan tingkat kredit yang disalurkan perbankan dengan jumlah dana pihak ketiga dari perbankan tersebut. Secara teori, jika semakin besar nilai LDR maka perbankan cenderung ekspansif dalam menyalurkan kreditnya, dengan demikian dapat membuka peluang bagi perbankan untuk memperoleh keuntungan (laba) dari kredit yang disalurkan tersebut. Menurut hasil penelitian yang dilakukan oleh Rinaldi (2020), Loan to Deposit Ratio berpengaruh signifikan terhadap Laba Bersih pada Bank BUMN yang Terdaftar di Bursa Efek Indonesia Periode 2014 - 2018.

H2: LDR berpengaruh positif terhadap Laba bersih perusahaan perbankan yang terdaftar di BEl.

Semakin tinggi NPL maka akan berbahaya bagi perusahaan perbankan. Tingkat NPL yang tinggi menandakan perbankan memiliki tingkat kredit bermasalah yang tinggi juga. Hal ini tentu akan menyebabkan laba perusahaan terganggu karena berpotensi kehilangan pendapatan dari kredit yang bermasalah tersebut. Menurut hasil penelitian yang dilakukan oleh Alamsyah (2017) Non Performing Loan (NPL) tidak berpengaruh signifikan dan negatif terhadap pertumbuhan laba Pada Perusahaan Perbankan Indonesia Periode 2011-2015. Non performing loan (NPL) merupakan kondisi dimana pihak peminjam tidak dapat memenuhi kewajibannya pada saat jatuh tempo, sehingga hal ini dapat menimbulkan kerugian kepada pihak kreditur atau bank sebagai penyedia dana. (Taswan, 2006).

H3: NPL berpengaruh negatif terhadap Laba bersih perusahaan perbankan yang terdaftar di BEl.

Rasio CASA,LDR, dan NPL yang ideal mencerminkan perbankan mampu menghasilkan laba secara maksimal dan bertumbuh. Menurut hasil penelitian yang dilakukan oleh Renjani dan Hendrawati (2020) secara simultan CASA, BOPO, dan Fee Based Income memilikipengaruh yang signifikan terhadap ROA pada bank umum syariah devisa periode 2015 - 2019. Hasil penelitian lain oleh Syeikh (2020) menunjukan bahwa secara simultan Capital Adequacy Ratio, Return on Asset dan Loan to Deposit Ratio berpengaruh signifikan terhadap Laba Bersih pada Bank BUMN di Bursa Efek Indonesia periode 2014-2018.

H4: CASA, LDR, NPL berpengaruh terhadap Laba bersih perusahaan perbankan yang terdaftar di BEI

\section{METODE PENELITIAN}

\section{Lokasi Penelitian}

Lokasi penelitian ini ada di Bursa Efek Indonesia (BEI). BEI merupakan regulator jalannya perdagangan pasar modal di Indonesia dan juga terdapat sekitar 730 perusahaan yang telah melantai di BEI. Selain itu BEI juga memiliki situs website bernama www.idx.co.id. 


\section{Populasi dan Sampel}

Sebanyak 43 perusahaan perbankan yang telah melantai di BEI per 31 desember 2020 menjadi populasi penelitian ini. Purposive sampling digunakan sebagai pemilihan sampel diantaranya (1) Perusahaan perbankan yang telah melantai di BEI, (2) Perusahaan perbankan yang menyajikan laporan keuangan selama tahun 2016-2020 (Periode pembukuan per 31 desember) dan (3) Termasuk kategori bank buku IV (modal inti diatas 30 Triliun) per 31 Desember 2020, sehingga jumlah sampel yang di dapat adalah 7 perusahaan.

Tabel 1.

\section{Kriteria Pengambilan Sampel}

\begin{tabular}{|l|l|c|}
\hline No & \multicolumn{1}{|c|}{ Kriteria } & Jumlah \\
\hline 1 & $\begin{array}{l}\text { Perusahaan perbankan yang terdaftar di } \\
\text { Bursa Efek Indonesia }\end{array}$ & 43 \\
\hline 2 & $\begin{array}{l}\text { Perusahaan perbankan yang menerbitkan } \\
\text { laporan keuangan selama periode 2016 - } \\
2020 \text { (Periode pembukuan per 31 } \\
\text { desember) Perusahaan perbankan yang } \\
\text { menerbitkan laporan keuangan selama } \\
\text { periode 2016 - 2020 (Periode pembukuan } \\
\text { per 31 desember) }\end{array}$ & $(36)$ \\
\hline 3 & $\begin{array}{l}\text { Termasuk kategori bank buku IV (modal inti } \\
\text { diatas 30 Triliun) per 31 Desember 2020. }\end{array}$ & \\
\hline & \multicolumn{1}{|c|}{ Jumlah sampel penelitian } & 7 Perusahaan \\
\hline
\end{tabular}

Berdasarkan kriteria yang telah ditetapkan pada penelitian ini, didapatkan 7 perusahaan untuk dijadikan sampel.

Tabel 2

Sampel Penelitian

\begin{tabular}{|c|c|l|}
\hline No & Kode Emiten & \multicolumn{1}{|c|}{ Nama Perusahaan } \\
\hline 1 & BBNI & Bank Negara Indonesia (Persero) \\
\hline 2 & BMRI & Bank Mandiri (Persero) Tbk. \\
\hline 3 & BBCA & Bank Central Asia Tbk. \\
\hline 4 & BBRI & Bank Rakyat Indonesia (Persero) \\
\hline 5 & BDMN & Bank Danamon Indonesia Tbk. \\
\hline 6 & BNGA & Bank CIMB Niaga Tbk. \\
\hline 7 & PNBN & Bank Panin Indonesia Tbk. \\
\hline
\end{tabular}

Sumber: www.ojk.go.id (2021)

\section{Metode Analisis}

Metode kuantitatif dengan teknik analisis data regresi linier berganda, uji asumsi klasik, uji hipotesis $\mathrm{t}$ dan $\mathrm{F}$ serta Koefisen determiasi $\left(\mathrm{R}^{2}\right)$ digunakan sebagai metode analisis data. Adapun rumus regresi linier berganda yakni:

$$
\begin{aligned}
& \mathrm{Y}=\mathrm{a}+\mathrm{X} 1 \mathrm{~b} 1+\mathrm{X} 2 \mathrm{~b} 2+\mathrm{X} 3 \mathrm{~b} 3+\mathrm{e} \\
& \text { Keterangan: } \\
& \mathrm{Y}=\text { Laba Bersih } \\
& \mathrm{a}=\text { Konstanta } \\
& \mathrm{X} 1=\text { CASA }
\end{aligned}
$$




$$
\begin{aligned}
& \mathrm{X} 2=\mathrm{LDR} \\
& \mathrm{X} 3=\mathrm{NPL} \\
& \mathrm{b} 1-3=\text { Koefisien regresi berganda } \\
& \mathrm{e}=\text { Standar erorr }
\end{aligned}
$$

\section{HASIL DAN PEMBAHASAN}

\section{Hasil Penelitian}

Statistik Deskriptif

Tabel 3

Descriptive Statistics

\begin{tabular}{|l|r|r|r|r|r|} 
& N & Minimum & Maximum & \multicolumn{1}{|c}{ Mean } & Std. Deviation \\
\hline CASA & 35 & 35.00 & 77.00 & 58.4771 & 12.50793 \\
\hline LDR & 35 & 65.80 & 107.90 & 89.4029 & 8.30965 \\
\hline NPL & 35 & 1.30 & 4.30 & 2.7086 & .75357 \\
\hline LABA BERSIH & 35 & 1088 & 34413 & 13651.43 & 11099.036 \\
\hline Valid N (listwise) & 35 & & & & \\
\hline
\end{tabular}

Berdasarkan statistik deskriptif diatas didapatkan nilai minimum untuk sampel penelitian berjumlah 35 ini untuk variabel CASA 35, LDR 65.8, NPL 1.30 dan laba bersih 1,088. Sedangkan unruk nilai maximum variabel CASA 77, LDR 107.9, NPL 4.3 dan laba bersih 34,413. Dan untuk nilai rata rata variabel CASA 56.4, LDR 89.4, NPL 2.7 dan Laba bersih 13,651.

\section{Uji Normalitas}

Tabel 4

Hasil Uji Normalitas One-Sample Kolmogorov-Smirnov Test

Unstandardized Residual

\begin{tabular}{llr}
\hline $\mathrm{N}$ & & \multicolumn{2}{c}{ Residual } \\
\hline Normal Parameters & & 34 \\
& Mean & .0000000 \\
\cline { 2 - 3 } Most Extreme Differences & Std. Deviation & 7060.70972600 \\
\cline { 2 - 3 } & Absolute & .146 \\
\cline { 2 - 3 } & Positive & .146 \\
\cline { 2 - 3 } & Negative & -.089 \\
\hline Test Statistic & & .146 \\
\hline Asymp. Sig. (2-tailed) & & $.062^{\mathrm{c}}$ \\
\hline
\end{tabular}

a. Test distribution is Normal.

b. Calculated from data.

c. Lilliefors Significance Correction.

Berdasarkan hasil olah data spss didapatkan hasil Asymp sig 2 tailed 0,062 yang lebih besar dari $\alpha=0,05$. Dari hasil tersebut menyatakan bahwa data telah terdistribusi normal karena nilai dari Asymp sig 2 tailed lebih besar dari a 0,05 yaitu sebesar 0,062.

\section{Uji Multikolinearitas}

Tabel 5

Hasil Uji Multikolinearitas 


\begin{tabular}{|c|c|c|c|c|c|c|c|c|}
\hline \multicolumn{9}{|c|}{ Coefficients $^{a}$} \\
\hline \multirow[b]{2}{*}{ Model } & & \multicolumn{2}{|c|}{$\begin{array}{l}\text { Unstandardized } \\
\text { Coefficients }\end{array}$} & \multirow{2}{*}{$\begin{array}{c}\text { Standardized } \\
\text { Coefficients } \\
\text { Beta }\end{array}$} & \multirow[b]{2}{*}{$\mathrm{t}$} & \multirow[b]{2}{*}{ Sig. } & \multicolumn{2}{|c|}{ Collinearity Statistics } \\
\hline & & $\mathrm{B}$ & Std. Error & & & & Tolerance & VIF \\
\hline 1 & (Constant) & -1299.872 & 19730.836 & & -.066 & .948 & & \\
\hline & CASA & 470.271 & 119.239 & .530 & 3.944 & .000 & .705 & 1.419 \\
\hline & LDR & 41.672 & 176.150 & .031 & .237 & .815 & .759 & 1.318 \\
\hline & NPL & -5981.660 & 1864.754 & -.406 & -3.208 & .003 & .794 & 1.260 \\
\hline
\end{tabular}

a. Dependent Variable:LABABERSIH

Dari hasil output SPSS diperoleh nilai tolerance sebesar 0,705 untuk variabel CASA, nilai tolerance sebesar 0,759 untuk variabel LDR dan nilai tolerance 0,794 untuk variabel NPL. Semua variabel tersebut memiliki nilai $>0,10$. Sedangkan nilai VIF 1.419 untuk variabel CASA, nilai VIF 1.318 untuk variabel LDR dan nilai VIF 1.260 untuk variabel NPL. Dimana semua variabel diatas memiliki nilai VIF $<10$. Berdasarkan hasil uji multikolinearitas tersebut dapat disimpulkan dari nilai VIF dan Tolerance tidak terjadi gejala multikolinieritas atau lolos uji multikolinieritas.

\section{Uji Heteroskedastisitas}

\begin{tabular}{|c|c|c|c|c|c|c|c|c|}
\hline \multicolumn{9}{|c|}{ Hasil Uji H } \\
\hline \multicolumn{9}{|c|}{ Coefficients $^{a}$} \\
\hline \multirow[b]{2}{*}{ Model } & & \multicolumn{2}{|c|}{ Unstandardized Coefficients } & \multirow{2}{*}{$\begin{array}{c}\text { Standardized } \\
\text { Coefficients } \\
\text { Beta }\end{array}$} & \multirow[b]{2}{*}{$\mathrm{t}$} & \multirow[b]{2}{*}{ Sig. } & \multicolumn{2}{|c|}{ Collinearity Statistics } \\
\hline & & $B$ & Std. Error & & & & Tolerance & VIF \\
\hline 1 & (Constant) & -1079.152 & 11470.891 & & -.094 & .926 & & \\
\hline & CASA & 97.406 & 69.322 & .284 & 1.405 & .170 & .705 & 1.419 \\
\hline & LDR & 30.201 & 102.408 & .057 & .295 & .770 & .759 & 1.318 \\
\hline & NPL & -682.728 & 1084.110 & -.120 & -.630 & .533 & .794 & 1.260 \\
\hline
\end{tabular}

Dari hasil olahan data tersbut didapatkan nilai signifikansi untuk ketiga variabel bebas tersebut $>0.05$. Variabel CASA memiliki nilai 0.170 , variabel LDR memiliki nilai 0.770 sedangkan untuk variabel NPL memiliki nilai 0.533 . Berdasarkan hasil uji glejser diatas maka data tersebut lolos uji heteroskedastisitas.

\section{Uji Autokorelasi}

\section{Tabel 7}

Hasil Uji Autokorelasi Model Summary ${ }^{\mathrm{b}}$

\begin{tabular}{l|c|cc|c|c} 
Model & $\mathrm{R}$ & $\mathrm{R}$ Square & $\begin{array}{c}\text { Adjusted R } \\
\text { Square }\end{array}$ & $\begin{array}{c}\text { Std. Error of the } \\
\text { Estimate }\end{array}$ & Durbin-Watson \\
\hline 1 & $.633^{\mathrm{a}}$ & .401 & .339 & .57144 & 1.788 \\
\hline $\begin{array}{l}\text { a. Predictors: (Constant), LAG_LNX3, LAG_LNX2, LAG_LNX1 } \\
\text { b. Dependent Variable:LAG_LNY }\end{array}$
\end{tabular}

Nilai Durbin - Watson dari hasil uji autokorelasi yakni sebesar 1.788. Jika dilihat dari syarat $\mathrm{dU}<\mathrm{d}<4$-dU maka menjadi $1.653<1.788<2.347$. (nilai dU pada ketentuan tersebut didapat dari tabel Durbin - Watson dimana untuk 3 variabel dan 35 sampel nilai dU adalah 1.653). 
Berdasarkan hasil uji Durbin - Watson maka data tersebut lolos uji autokorelasi

\section{Analisis Regresi Linier Berganda}

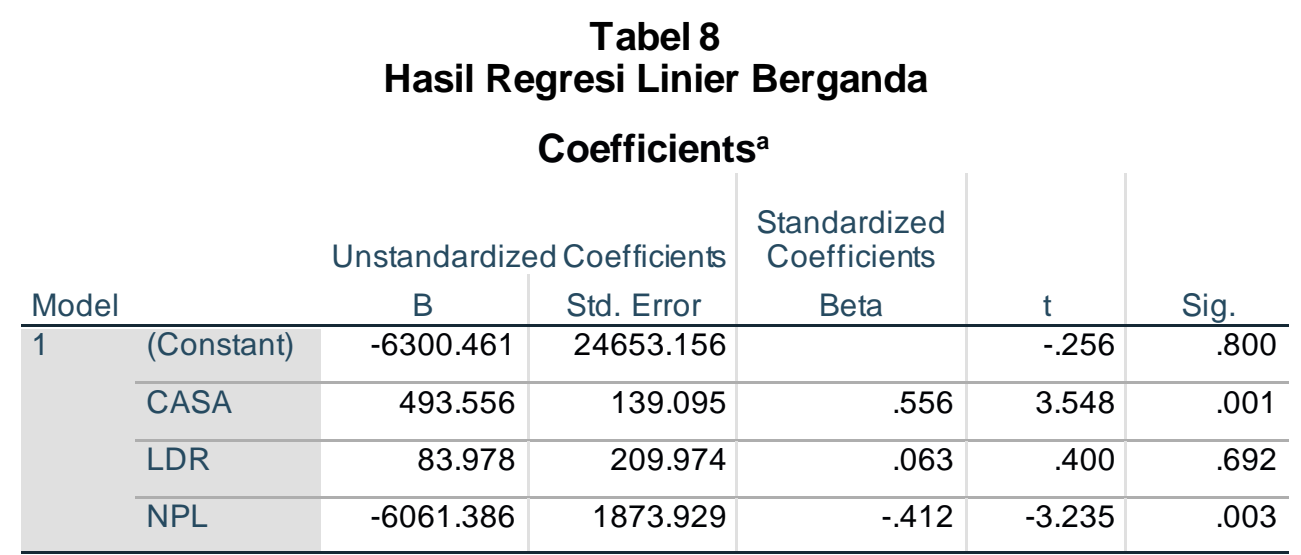

a. Dependent Variable:LABA BERSIH

Berdasarkan hasil analisis di atas maka didapat persamaan regresi seperti berikut :

Laba Bersih $=(-6300.461)+(493.556) \mathrm{CASA}+(83.978) \mathrm{LDR}-6061.386 \mathrm{NPL}+\mathrm{e}$

1. Nilai Konstanta -6300.461 berarti jika CASA (X1), LDR (X2) dan NPL (X3) dalam keadaan konstan / 0 maka nilai laba bersih akan menurun.

2. Nilai CASA $\beta 1$ adalah sebesar 493.556 yang berarti jika nilai $C A S A$ naik 1 satuan maka akan menaikkan nilai laba bersih sebesar 493.556

3. Nilai LDR $\beta 2$ adalah sebesar 83.978 yang berarti jika nilai LDR naik 1 satuan makaakan menaikkan laba bersih saham sebesar 83.978

4. Nilai NPL $\beta 3$ adalah sebesar -6061.386 yang berarti jika nilai NPL naik 1 satuan maka akan menurunkan nilai laba bersih sebesar 6061.386

\section{Uji t (Uji Parsial)}

\begin{tabular}{|c|c|c|c|c|c|c|}
\hline & & & $\begin{array}{c}\text { Tabel } 9 \\
\text { Hasil Uji } \\
\text { Soefficient }\end{array}$ & & & \\
\hline & & Unstandardize & Coefficients & $\begin{array}{l}\text { Standardized } \\
\text { Coefficients }\end{array}$ & & \\
\hline Model & & B & Std. Error & Beta & $\mathrm{t}$ & Sig. \\
\hline 1 & (Constant) & -6300.461 & 24653.156 & & -.256 & .800 \\
\hline & CASA & 493.556 & 139.095 & .556 & 3.548 & .001 \\
\hline & LDR & 83.978 & 209.974 & .063 & .400 & .692 \\
\hline & NPL & -6061.386 & 1873.929 & -.412 & -3.235 & .003 \\
\hline
\end{tabular}

a. Dependent Variable: LABA BERSIH

Berdasarkan hasil perhitungan Uji t diatas didapat hasil sebagai berikut :

a. Variabel CASA mendapat nilai $\mathrm{t}=3.548$ dan hasil dari nilai signifikansinya adalah 0,01 lebih kecil dari $\alpha=0,05$ Sedangkan untuk koefisien beta bernilai positif. Hal ini berarti secara parsial variabel CASA berpengaruh positif terhadap laba bersih. Maka dari itu, hipotesis $1(\mathrm{H} 1)$ untuk penelitian ini diterima 
b. Variabel $L D R$ mendapat nilai $\mathrm{t}=0.400$ dan hasil dari nilai signifikansinya adalah 0,692 lebih besar dari $\alpha=0,05$. Hal ini berarti secara parsial variabel $L D R$ tidak berpengaruh terhadap laba bersih. Maka dari itu, hipotesis $2(\mathrm{H} 2)$ untuk penelitian ini ditolak.

c. Variabel NPL mendapat nilai $t=-3.235$ dan hasil dari nilai signifikansinya adalah 0,03 lebih kecil dari nilai $\alpha=0,05$. Sedangkan untuk koefisien beta bernilai negatif. Hal ini berarti secara parsial variabel NPL berpengaruh negatif terhadap laba bersih. Maka dari itu, hipotesis $3(\mathrm{H} 3)$ untuk penelitian ini diterima.

\section{Uji F (Uji Simultan)}

Tabel 10

\section{Hasil Uji F}

\begin{tabular}{|c|c|c|c|c|c|c|}
\hline \multirow[b]{2}{*}{ Model } & \multicolumn{6}{|c|}{ ANOVAa $^{a}$} \\
\hline & & $\begin{array}{l}\text { Sum of } \\
\text { Squares }\end{array}$ & $d f$ & Mean Square & $\mathrm{F}$ & \\
\hline 1 & Regression & $\begin{array}{r}2542175979.0 \\
00\end{array}$ & 3 & $\begin{array}{r}847391993.00 \\
0\end{array}$ & 15.957 & $.000^{\mathrm{k}}$ \\
\hline & Residual & $\begin{array}{r}1646236359.0 \\
00\end{array}$ & 31 & 53104398.690 & & \\
\hline & Total & $\begin{array}{r}4188412339.0 \\
00\end{array}$ & 34 & & & \\
\hline
\end{tabular}

Berdasarkan hasil analisis diatasi didapat hasil $F_{\text {Hitung }}$ sebesar $15.957>$ dari nilai $F_{\text {tabel }}$ yaitu didapat nilai sebesar 2.901 dengan nilai signifikansi 0.000 lebih kecil dari 0.05 . Nilai $F_{\text {tabel }}$ didapat dari tabel distribusi $F(k ; n-3)$. Berdasarkan hasil uji simultan diatas maka didapatkan hasil CASA, LDR, dan NPL berpengaruh signifikan terhadap laba bersih perusahaan perbankan yang terdaftar di BEI periode 2016-2020. Maka dari itu, hipotesis $4(\mathrm{H} 4)$ diterima.

\section{Uji Koefisien Determinasi $\left(R^{2}\right)$}

\section{Tabel 11 \\ Hasil Uji $\mathbf{R}^{2}$}

\begin{tabular}{ll|c|c|c} 
& \multicolumn{4}{c}{ Model Summary } \\
Model & $R$ & R Square & $\begin{array}{c}\text { Adjusted R } \\
\text { Square }\end{array}$ & $\begin{array}{c}\text { Std. Error of the } \\
\text { Estimate }\end{array}$ \\
\hline 1 & $.779^{\mathrm{a}}$ & .607 & .569 & 7287.276 \\
\hline
\end{tabular}

a. Predictors: (Constant), NPL, CASA, LDR

Berdasarkan hasil uji koefisien determinasi didapat nilai $\mathrm{R}^{2}$ adalah 0.607 yang artinya kemampuan CASA,LDR, dan NPL dalam memberi peranan terhadap laba bersih adalah sebesar $0,607 \times 100 \%=60.7 \%$ dan sisanya $39.3 \%$ dipengaruhi oleh faktor lain yang tidak diuji dalam penelitian ini.

\section{PEMBAHASAN}

\section{Pengaruh Current Account Saving Account terhadap Laba Bersih}

Berdasarkan hasil analisis uji t didapat nilai signifikan untuk variabel Current Account Saving Account sebesar 0.001 yang menunjukan variabel CASA berpengaruh terhadap laba bersih. 
Sedangkan koefisien beta memiliki arah positif menandakan bahwa Current Account Saving Account berpengaruh positif terhadap laba bersih. Semakin positif perolehan Current Account Saving Account maka semakin positif pula laba bersih yang didapat perbankan. Hal ini dikarenakan CASA merupakan porsi dana murah dalam dana pihak ketiga yang dihimpun perbankan. Dikatakan dana murah karena beban bunga yang harus dikeluarkan untuk jenis ini lebih rendah dibanding deposito. Semakin tinggi porsi dana murah yang dihimpun maka semakin rendah beban bunga yang harus dikeluarkan perbankan dalam menghimpun dana pihak ketiga sehingga pada akhirnya akan memperbesar potensi perolehan laba bersih perbankan tersebut. Berdasarkan Signalling Theory, investor mendapatkan sinyal yang baik untuk melakukan keputusan investasi, jika rasio Current Account Saving Account (CASA) tinggi maka laba yang dapat dihasilkan perbankan tersebut berpotensi lebih tinggi sehingga investor dapat memilih saham perbankan yang memiliki rasio CASA yang tinggi. Hasil yang sama juga diteliti oleh Renjani \& Hendrawati (2020) CASA berpengaruh positif terhadap ROA bank umum syariah devisa tahun 2015-2019. Demikian juga dengan penelitian lain yang menunjukan Current Account Saving Account CASA dapat meningkatkan profitabilitas perbankan (Khabibah et al., 2020).

\section{Pengaruh Loan To Deposit Ratio Terhadap Laba Bersih}

Berdasarkan hasil uji t didapat nilai signifikan untuk variabel Loan To Deposit Ratio sebesar 0.692 yang menunjukan variabel LDR tidak berpengaruh terhadap laba bersih. Dengan demikian hipotesis kedua penelitian ini ditolak. Hal ini dikarenakan jika nilai LDR tinggi maka kredit yang disalurkan perbankan menjadi tinggi. Kredit yang tinggi belum bisa dikatakan kredit berkualitas karena bisa saja terdapat risiko kredit bermasalah dalam kredit yang disalurkan tersebut sehingga belum tentu dapat meningkatkan perolehan laba bersih. Nilai LDR yang tinggi juga bisa membahayakan perbankan karena dana yang tersedia menjadi sedikit dalam artian likuiditas perbankan sedikit terganggu karena mayoritas dana nya disalurkan dalam kredit sehingga perlu bagi perbankan untuk menjaga rasio ini agar tetap tetap optimal. Hasil penelitian ini sesuai dengan penelitian Katharina et al (2021) bahwa LDR tidak berpengaruh terhadap Pertumbuhan laba dalam perusahaan Perbankan yang tercatat di BEI tahun 2017-2019. Demikian juga dengan penelitian lain yang menyatakan LDR tidak berpengaruh pada profitabilitas Bank Umum Swasta Nasional Devisa tahun 2012-2016 (Nasya Batari Ayunda Praja, 2018).

\section{Pengaruh Non Performing Loan Terhadap Laba Bersih}

Berdasarkan hasil uji t didapat hasil signifikan t untuk variabel Non Performing Loan adalah sebesar 0,003 yang berarti bahwa NPL secara parsial berpengaruh terhadap laba bersih. Sedangkan koefisien beta memiliki arah negatif menandakan bahwa NPL berpengaruh negatif terhadap laba bersih. Semakin positif perolehan NPL maka semakin negatif / berkurang laba bersih yang didapat perbankan. Hal ini disebabkan jika rasio NPL tinggi maka semakin tinggi juga kredit bermasalah yang dimiliki perbankan yang berakibat pada menurunnya potensi laba bersih yang bisa diperoleh. Tinggi nya NPL mengakibatkan perbankan harus menyiapkan beban pencadangan yang lebih tinggi untuk mengatasi risiko kredit yang bermasalah tersebut. Semakin tinggi beban pencadangan maka perolehan laba bersih perbankan akan semakin berkurang sehingga mengakibatkan efisiensi perbankan terganggu. Hal ini sesuai dengan hasil penelitian Praja (2018) bahwa NPL berpengaruh negatif terhadap profitabilitas Bank Umum Swasta Nasional (BUSN) Devisa periode 2012-2016 dan penelitian lain menyatakan bahwa NPL berpengaruh terhadap perubahan laba Bank Umum yang Terdaftar di BEI tahun 2013-2017(Putri et al., 2019).

\section{Pengaruh Current Account Saving Account, Loan To Deposit Ratio, dan Non Performing Loan terhadap Laba Bersih}

Berdasarkan hasil uji $F$ didapatkan nilai signifikan yaitu $0,000<\alpha=0,05$ yang menunjukan bahwa CASA, LDR dan NPL secara simultan berpengaruh terhadap laba bersih. Hal ini disebabkan ketiga rasio tersebut berperan dalam pembentukan laba bersih perbankan. Jika salah satu rasio tersebut mengalami perubahan yang signifikan maka laba bersih juga akan berpengaruh. Hal ini 
sesuai dengan penelitian Renjani \& Hendrawati (2020), secara simultan CASA, BOPO, dan Fee Based Income berpengaruh terhadap ROA bank umum syariah devisa tahun 2015 - 2019. Demikian juga dengan hasil penelitian lain bahwa CAR, ROA, LDR dan NPL secara simultan berpengaruh signifikan Terhadap Laba Bersih Bank BUMN yang Terdaftar di Bursa Efek Indonesia tahun 2014 - 2018. (Surono et al., 2020)

\section{KESIMPULAN DAN SARAN}

\section{Simpulan}

Kesimpulan dari penelitian ini adalah:

1. Secara parsial ditarik kesimpulan bahwa CASA berpengaruh positif terhadap Laba Bersih.

2. Secara parsial ditarik kesimpulan bahwa $L D R$ tidak berpengaruh terhadap Laba Bersih.

3. Secara parsial ditarik kesimpulan bahwa NPL berpengaruh negatif terhadap Laba Bersih.

4. Secara simultan ditarik kesimpulan bahwa CASA, LDR NPL berpengaruh signifikan terhadap Laba Bersih.

\section{Saran}

1. Bagi Investor yang ingin berinvestasi di sektor perbankan sebaiknya perlu melakukan analisis fundamental terkait perusahaan mana yang akan diinvestasikan. Beberapa rasio yang dapat digunakan untuk melalukan analisis pada sektor perbankan yakni rasio CASA, LDR, dan NPL.

2. Bagi perusahaan sebaiknya selalu meningkatkan dan menjaga kinerja perusahaannya, khususnya dalam mengoptimalkan ketiga rasio yang digunakan dalam peneltian ini.

3. Bagi profesi equity analyst di pasar modal, sebaiknya dapat menggunakan penelitian ini sebagai referensi untuk memperdalam analisa di sektor perbankan sehingga dapat memberikan riset yang berkualitas kepada nasabah dan masyarakat pada umumnya.

4. Bagi peneliti lainnya diharapkan menggunakan variabel bebas lainnya ataupun menggunakan sampel yang berbeda dalam penelitian ini sehingga dapat semakin memberikan gambaran terkait penelitian serupa.

\section{DAFTAR PUSTAKA}

Ali, M. (2017). Pengaruh Net Interest Margin (NIM), Biaya Operasional Terhadap Pendapatan Operasional (BOPO), Loan to Deposit Ratio (LDR) dan Non Performing Loan (NPL) Terhadap Return On Assets (ROA). Jurnal Riset Akuntansi dan Keuangan, 5(2), 1377-1392.

Alamsyah, S. (2017). pengaruh capital adequacy ratio (CAR), non performing loan (NPL), loan to deposit ratio (LDR), return on asset (ROA) dan net interest margin (NIM) terhadap pertumbuhan laba (Studi Empiris Pada Perusahaan Perbankan Indonesia Periode 2011-2015). COMPETITIVE Jurnal Akuntansi dan Keuangan, 2(1), 32-54.

Arikunto, S. 2000. Prosedur Penelitian Suatu Pendekatan Praktek. Jakarta: Rineka Cipta

Ali. (2004). Asset Liability Management: Menyiasati Risiko Pasar dan Risiko Operasional dalam Perbankan. Jakarta: PT Elex Media Komputindo

Bursa Efek Indonesia, www.idx.co.id

Dendawijaya, Lukman, (2013). Manajemen Perbankan, Jakarta: Ghalia Indonesia,

Darmawi, Herman. (2011). Manajemen Perbankan. Jakarta: Bumi Aksara 
Fahmi, Irham. (2012). Analisis Kinerja Keuangan, Bandung: Alfabeta

Ginting, S. (2019). Analisis Pengaruh CAR, BOPO, NPM dan LDR Terhadap Pertumbuhan Laba dengan Suku Bunga Sebagai Variabel Moderasi Pada Perusahaan Perbankan yang Terdaftar di Bursa Efek Indonesia Periode 2013-2016. Jurnal Wira Ekonomi Mikroskil: JWEM, 9(1), 97106.

Ghozali, I. 2016, "Aplikasi Analisis Multivariete Dengan Program IBM SPSS 23 Edisi 8, Badan Penerbit Universitas Diponegoro, Semarang

Hasibuan, E., Theresya, H., \& Gaol, L. F. L. (2021). Pengaruh Dana Pihak Ketiga, Biaya Operasional Pendapatan Operasional, dan Loan to Deposit Ratio Terhadap Profitabilitas Pada Perusahaan Perbankan yang Terdaftar di Bursa Efek Indonesia Periode 2016-2018. Ekonomi, Keuangan, Investasi Dan Syariah (EKUITAS), 2(2), 194-199.

Harmono. (2014). Manajemen Keuangan Berbasis balanced scored. Jakarta: PT Bumi Aksara

Hanafi, M. M., dan A. Halim. (2012). Analisis Laporan Keuangan. Edisi Keempat. Cetakan Kedua. Unit Penerbit dan Percetakan Sekolah Tinggi IImu Manajemen YKPN. Yogyakarta.

Indriantoro, Nur., dan Supomo, Bambang. (2013). Metodologi Penelitian Bisnis Untuk Akuntansi \& Manajemen. Yogyakarta: BPFE.

Khabibah, N. A., Octisari, S. K., \& Nugraheni, A. P. (2020). CASA, NIM, dan Profitabilitas Perbankan di Indonesia. Jurnal Aplikasi Akuntansi, 5(1), 52-71

Katharina, N., Christine, C., Wijaya, F., \& Clorinda, C. C. (2021). Pengaruh kinerja keuangan terhadap pertumbuhan laba pada perusahaan perbankan yang terdaftar di bursa efek indonesia periode 2017-2019. Warta Dharmawangsa, 15(1), 128-146.

Kasmir, 2014. Analisis Laporan Keuangan, cetakan ke-7. Jakarta: PT RajaGrafindo Persada.

Karim, Adiwarman. 2010. Bank Islam Analisis Fiqih Dan Keuangan. Jakarta: Raja Grafindo persada.

Kuncoro, Mudrajad. 2009. Metode Riset untuk Bisnis dan Ekonomi.

Kasmir. (2016). Analisis Laporan Keuangan. Jakarta: Raja Grafindo Persada.

Kustodian Sentral Efek Indonesia, www.ksei.co.id

Lestari, W. D., \& Setianegara, R. G. (2020). ANALISIS PENGARUH NIM, BOPO, LDR, D AN NPL TERHADAP PROFITABILITAS (Studi Kasus Pada Bank Umum Yang Listed Di Bursa Efek Indonesia Periode 2014-2018). KEUNIS, 8(1), 82-92.

Natalia, E. Y. (2017). Analisis Faktor-Faktor Yang Berpengaruh Terhadap Perubahan Laba Pada Perusahaan Perbankan yang Terdaftar di Bei. Journal of Accounting and Management Innovation, 1(2), 129-142.

Otoritas Jasa Keuangan, www.ojk.go.id

Putri, V. S., \& Yuliandhari, W. S. (2021). Analisis Pengaruh Capital Adequacy Ratio (car), Non Performing Loan (npl), Dan Loan Deposit Ratio (ldr) Terhadap Profitabilitas Perbankan (studi Pada Perusahaan Perbankan Yang Terdaftar Di Bursa Efek Indonesia Tahun 2016-2018). eProceedings of Management, 7(3) 
Poerwanti, R., \& Kartika, T. P. D. (2018). The Effect of CAR, NPL \& LDR On The Profit Improvement of Regional Development Bank In Indonesia by Using Credit Growth as Intervening Variable (Research on REgional Development Banks in Java, Bali \& NTT) Period 2011-2015. International Journal of Entrepreneurship and Business Development, 1(2), 188-202.

Renjani, R., \& Hendrawati, H. (2020). Analisis pengaruh current account saving account, operating efficiency ratio, dan fee based income terhadap profitabilitas pada bank umum syariah devisa periode 2015-2019.

Rohmiati, E., Winarni, W., \& Soebroto, N. W. (2019). Analisis Pengaruh Bopo, Npl, Nim, Dan Ldr Terhadap Profitabilitas Pada Bank Umum Di Indonesia Periode 2012-2017. Keunis, 7(1), 3448.

Rosyid, P. I., \& Irawan Noor, M. (2018). Effect of Capital Adequacy Ratio (CAR), Loan to Deposit Ratio (LDR) and Return on Equity (ROE) on Share Price PT Bank Danamon Indonesia, TBK. International Journal of Business and Applied Social Science, 4(1), 87-101.

Salim, M. N., \& Mundung, L. O. (2020). ROA DETERMINANTS AND IMPACTS ON CAR (STUDY IN THE FIVE LARGEST PRIVATE BANKS IN INDONESIA 2009-2018). Dinasti International Journal of Economics, Finance \& Accounting, 1(4), 629-641.

Sari, F. N., \& Endri, E. (2019). Determinants of Return on Assets (ROA) On Conventional Banks Listed On Indonesian Stock Exchange (IDX) Period 2013-2017. IOSR Journal of Business and Management (IOSR-JBM), 21(4), 52-62.

Saleh, D. S., \& Winarso, E. (2021). Analysis of non-performing loans (NPL) and loan to deposit ratio (LDR) towards profitability. International Journal of Multicultural and Multireligious Understanding, 8(1), 423-436.

Setiawan, A., \& Hermanto, B. (2017). Comparative study: determinant on banking profitability between buku 4 and buku 3 bank in indonesia. Benefit: Jurnal Manajemen dan Bisnis, 2(1), 92-101.

Sugiyono. (2018). Metode Penelitian Kuantitatif. Bandung: Alfabeta

Surono, Y., Syeikh, S., \& Rinaldi, A. (2020). Pengaruh Capital Adequacy Ratio, Return on Asset, Loan to Deposit Ratio dan Non Performing Loan Terhadap Laba Bersih pada Bank BUMN yang Terdaftar di Bursa Efek Indonesia Periode 2014-2018. J-MAS (Jurnal Manajemen dan Sains), 5(1), 113-118.

Taswan. (2006). Manajemen Perbankan, Konsep, Teknik \& Aplikasi. UPP STIM YKPN. Yogyakarta

Uly ,Yohana Artha (2020) jumlah-investor-pasar-modal-indonesia-masih-tertinggal-dari-singapura. https://money.kompas.com/read/2020/10/22/103000226/jumlah-investor-pasar-modal-indonesiamasih-tertinggal-dari-singapura-dan?page=all 